УДК 632.51:633.18

DOI https://doi.org/10.32848/agrar.innov.2021.5.14

\title{
РАЦІОНАЛЬНИЙ ШЛЯХ ПІДВИЩЕННЯ РІВНЯ ЕФЕКТИВНОСТІ СИСТЕМИ ЗАХИСТУ ПОСІВІВ РИСУ ВІД БУР'ЯНІВ
}

\author{
ЦІЛИнко Л.М. - науковий співробітник \\ https://orcid.org/0000-0002-5032-2767 \\ Інститут рису Національної академії аграрних наук України
}

Постановка проблеми. Рис посівний (Oryza sativa L.) - одна 3 головних продовольчих культур, яка разом із пшеницею і кукурудзою є основою продовольчої безпеки людства. Особливо велике значення рису як основного продукту харчування жителів Південно-Східної Азії. Для населення Європи, зокрема України, рис посівний це традиційна круп'яна культура, що стабільно посідає вагоме місце в раціоні жителів. Забезпечення населення рисом відбувається як за рахунок імпорту, так і за рахунок власного вирощування в південних регіонах країни.

За своїм походженням рис посівний як вид рослин був сформований у Південно-Східній Азії, тому дуже вимогливий до наявності тепла, води і тривалого вегетаційного періоду. Зона вирощування посівів рису посівного у нашій країні є однією з найбільш північних для цієї культури, тому має свою специфіку [1-3]. Поєднання достатньої кількості тепла, вологи та інтенсивного сонячного освітлення $€$ сприятливою умовою вегетації не лише для рослин рису посівного, але й для багатьох видів диких трав'янистих рослин, що є бур'янами.

У посівах рису нашої країни відомий 241 вид бур'янів, що пристосовані до вегетації в таких специфічних умовах. Серед видів бур'янів на орних землях, де традиційно вирощують посіви рису посівного, найбільш характерними є види, які називають болотними [4-6]. Вони легко витримують періодичне затоплення й вимагають практично тих самих умов вегетації, що й рослини рису посівного. У зоні рисосіяння нашої країни це перш за все рослини куги гострокінцевої (Scirpus mucronotus L.), куги розлогої (Scirpus supines L.), бульбоочерету (Bolboschoenus compactus Drop.) з ботанічної родини Осокові (Cyperaceae). Серед однорічних видів бур'янів поширені також представники ботанічної родини Тонконогові (Poaceae), просо півняче (Echinochloa crusgalli (L.) Pal. Beauv.), просо рисове (Echinochloa orysicola Vasing.) тощо [7-9].

Спеціалізація аграрних господарств на вирощуванні такої цінної культури і висока концентрація посівів рису посівного часто приводять до порушення науково обґрунтованих рисових сівозмін і формування значного рівня потенційної засміченості орного шару ґрунту насінням найбільш масових і проблемних для їх успішного контролювання видів бур'янів [10; 11].

Аналіз останніх досліджень і публікацій. За умов інтенсивного вирощування посівів рису їх захист від негативного впливу бур'янів здійснюють за допомогою спеціалізованих селективних гербіцидів. Проте широка практика їх регулярного застосування у посівах рисових чеків призводить до виникнення небажаного побічного ефекту, а саме швидкого формування резистентних популяцій масових видів бур'янів до дії таких спеціалізованих гербіцидів і зниження рівня ефективності заходів захисту [12-14]. Досвід аграрного виробництва доводить, що вже через 7-10 років широкого використання у посівах рису посівного ще недавно ефективний гербіцид реально знижує здатність захищати рослини культури від потужних конкурентів бур'янів, тобто у рисових чеках бур'яни сформували популяції рослин, що адаптувались до діючих речовин гербіциду. Подібні процеси відбуваються глобально в різних регіонах вирощування посівів рису посівного. Для умов нашої країни, де площі виробничого вирощування цієї цінної продовольчої культури досить обмежені, питання ефективного захисту посівів від негативного впливу бур'янів $€$ дуже актуальними. Присутність бур'янів у посівах рису посівного знижує рівень урожайності культури від 80 до 15 і більше [15-18].

Специфріка засміченості орного шару ґрунту в рисових чеках насінням та органами вегетативного розмноження бур'янів вимагає для ефективного їх контролювання застосування гербіцидів з відповідною біохімічною спрямованістю їх дії. Одними з найбільш масових видів бур'янів у посівах рису у нашій зоні вирощування $є$ просо півняче (Echinochloa crus-galli (L.) Pal. Beauv.) і куга гострокінцева (Scirpus mucronotus L.). Проте застосування гербіцидів, що контролюють такі види бур'янів, ускладнене тією обставиною, що рис посівний теж є видом, що належить до ботанічної родини Тонконогові, тому потрібні препарати, що здатні перш за все контролювати бур'яни 3 ботанічних родин Тонконогові та Осокові. Досягати такого результату найбільш раціонально шляхом використання відповідних антидотів або адсорбентів, що забезпечать необхідний рівень селективності дії гербіцидів до рослин рису посівного [19; 20; 21].

Мета статті. Метою дослідження $є$ оцінювання причин недостатньої ефективності застосування відомих гербіцидів і розроблення шляхів ефективного контролювання бур'янів та отримання високих врожаїв рису посівного.

Матеріали та методика досліджень. Для дослідження актуальної проблеми ефективного захисту посівів рису від бур'янів були заплановані польові досліди, що були реалізовані у 2018-2020 рр. Дослідження були польовими, дрібно ділянковими.

Проводили досліди на дослідних полях Інституту рису НААН України (с. Антонівка, Скадовський район, Херсонська область). Ґрунтово-кліматична зона помірно-континентальна, посушлива з достатньою кількістю сонячного світла та тепла для нормального росту й розвитку рослин рису посівного у процесі їх вегетації. 
Ґрунтовий покрив представлений темно-каштановими вторинно осолонцьованими ґрунтами. Ґрунт має добре розвинений гумусовий профіль. Кипіння від нанесення $\mathrm{HCl}$ спостерігають із глибини $70 \mathrm{~cm}$. Ґрунт $\epsilon$ слабко солонцюватим. За гранулометричним складом ґрунт належить до піщано-середньосуглинкового з перевагою в орному шарі фракції піску. Крупного пилу міститься 30,0, а мулу - 21,74\%.

Розмір посівної дослідної ділянки становить 66 м², облікової - 50 м². Досліди закладали у 4-разовій повторності. Розміщення ділянок регулярне у два яруси.

Дослідження передбачали реалізацію такої схеми варіантів.

1) Посіви рису вегетують без проведення заходів захисту від бур'янів.

2) Посіви рису вегетують 3 використанням для захисту від бур'янів системи послідовних обприскувань гербіцидами Комманд, 48 КЕ у нормі витрати 0,5 л/га в ґрунт після проведення сівби. Гербіцид Топшот, 113 ОД у нормі витрати 3,0 л/га вносять по сходах за формування трьох листків рослин рису.

3) Посіви рису вегетують із використанням для захисту від бур'янів системи послідовних обприскувань гербіцидами Фронтьєр Оптіма,72 КЕ у нормі витрати 1,2 л/га в ґрунт після проведення сівби. Гербіцид Топшот, 113 ОД у нормі витрати 3,0 л/га вносять по сходах за формування трьох листків рослин рису.

4) Посіви рису вегетують з використанням для захисту від бур'янів системи послідовних обприскувань гербіцидами Дуал Голд, 960 ЕС у нормі витрати 1,4 л/га в ґрунт після проведення сівби. Гербіцид Топшот, 113 ОД у нормі витрати 3,0 л/га вносять по сходах за формування трьох листків рослин рису.

5) Посіви рису вегетують без негативного впливу бур'янів. Протягом вегетації проводять п'ять послідовних ручних прополювань.

Досліди, обліки, спостереження та аналізи проводили відповідно до специфіки вимог «Методики випробування й застосування пестицидів» за редакцією професора» С.О. Трибеля [22], «Методів досліджень ґрунту і рослин» [23], «Методики проведення досліджень у буряківництві» [24].

Внесення гербіцидів (обприскування) у дослідах здійснювали спеціальним газовим обприскувачем з редуктором постійного тиску, на колесах і зі штангою. Розпилювачі щілинного типу. Робочий тиск становив 2,1 атм. Витрата робочої рідини складала 200 л/га. Гербіциди ґрунтової дії вносили після проведення сівби та до появи сходів рослин культури. По сходах обприскування проводили у фазу формування у рослин рису посівного трьох листків.

Обліки бур'янів здійснювали кількісно-ваговим методом перед проведенням обприскувань посівів по сходах і через 10 діб після проведення заходів захисту. Обліки маси бур'янів у посівах здійснювали на соту добу після появи сходів рису посівного шляхом зрізування надземних частин рослин біля поверхні ґрунту і зважування їх за видами.

Рівень урожайності посівів рису визначали шляхом суцільного збирання облікових ділянок на всіх повто- реннях спеціальним селекційним комбайном «Сампо2000» з подальшим перерахунком у т/га.

Результати досліджень. Проведені аналізи рівня потенційної засміченості орного шару ґрунту насінням та органами вегетативного розмноження бур'янів дали змогу встановити видовий склад і кількість насіння, що здатне до проростання 3 верхнього (0-10 см) горизонту. Загальні запаси живого насіння у верхньому горизонті складали в середньому 12 987,8 шт./м². 3 них найбільш масовим було насіння проса півнячого, а саме 1381 шт./м².

Виконання перших обліків сходів бур'янів (обліки поводили в час формування рослинами рису трьох листків) підтвердило виявлену в процесі аналізу відмитого 3 ґрунту насіння структуру забур'яненості. На ділянках варіанта 1 (забур'янений контроль) загальна кількість сходів бур'янів була дуже високою і становила в середньому за роки проведення досліджень 426,5 шт./ ${ }^{2}$ посівів рису. 3 них сходи проса півнячого (Echinochloa crus-galli (L.) Pal. Beauv.) складали 281,3 шт./M², або $65,9 \%$ від загальної кількості рослин бур'янів, портулака городнього (Portulaca oleraceae L.) - 54,3 шт./M², або $12,7 \%$, куги гострокінцевої (Scirpus mucronotus L.) 43,1 шт./M², або 10,1\%, лободи білої (Chenopodium album L.) - 11,5 шт./M², або 2,7\%, щириці звичайної (загнутої) (Amaranthus retroflexus L.) - 10,8 шт./м², або 2,5\% (табл. 1).

Для забезпечення необхідного рівня контролювання сходів такої кількості бур'янів у посівах рису загальна ефрективність дії гербіцидів має наближатись до 100\%, що в умовах виробництва досягти дуже складно і часто неможливо, тому більш доцільно у системі захисту посівів від бур'янів передбачити проведення послідовної дії гербіцидів і, відповідно, поетапне зниження рівня їх присутності у посівах культури. В умовах достатнього рівня зволоження верхнього горизонту ґрунту (для рисових чеків оптимальна ситуація) цілком доцільно розраховувати на високий рівень ефективності препаратів, що діють на проростки і сходи рослин бур'янів через ґрунт.

Структура потенційної засміченості орного шару ґрунту доводить необхідність використання гербіцидів ґрунтової дії, що мають спрямованість перш за все проти рослин однорічних представників ботанічних родин Тонконогові (Роасеае (Злакові - Gramineae)) та Осокові (Суреriaceae). Проте такі препарати проявляють високу біохімічну активність на рослини рису посівного. Необхідне отримання ефекту селективності дії таких гербіцидів до рослин культури, що може бути досягнуте за рахунок застосування антидотів або фрізичних адсорбентів. Оскільки з антидотами для посівів рису посівного в нашій країні питання відкрите, то у дослідах було застосовано захисну для проростків і сходів рослин культури дію фрізичних адсорбентів.

Гербіцид ґрунтової дії Комманд, 48 КЕ має перш за все спрямованість дії на проростки і сходи рослин бур'янів класу Дводольні (Dicotyledone). Його нині застосовують у процесі вирощування посівів рису, тому він був включений у схему проведення досліджень як своєрідний виробничий варіант (варіант 2). Інші варіанти досліду передбачали використання гербіцидів ґрунтової дії з обов'язковою присутністю фрізичного адсорбенту 
(подрібненого деревного вугілля). Рослини культури реагували на присутність гербіцидів ґрунтової дії неоднаково (табл. 1).

Рослини рису посівного традиційно мають значну різницю між показниками лабораторної і польової схожості. Така різниця набагато більша порівняно з різницею у польових зернових культур, що проростають за оптимальних умов вегетації, тому в дослідах норму висіву зернівок рису розраховували на 100\% лабораторну здатність до проростання. Норма висіву була однакова на всіх посівах варіантів досліду і становила 667 зернівок. На ділянках посівів контролю (варіанти 1 і 5) середні показники польової схожості за роки досліджень становили 344 рослини культури на м² посівів, тобто рівень зниження порівняно з лабораторною здатністю до проростання становив 51,2\%. Використання у посівах гербіциду Комманд, 48 КЕ проявляло свій вплив не лише на проростки бур'янів перш за все класу Дводольні, але й на проростки рослин рису посівного. Кількість сходів рослин культури у посівах, де застосовували такий гербіцид, становила в середньому 167 шт./м², тобто, крім різниці лабораторної і польової схожості, проявлялась фрітотоксичність діючої речовини гербіциду. Вона була на рівні 23,8\%.

Використання гербіцидів ґрунтової дії, що мають спрямованість дії проти рослин ботанічної родини Тонконогові, проводили 3 внесенням фізичних адсорбентів, які ослаблювали токсичний вплив таких препаратів на проростки і сходи рослин рису посівного. Всі використані у дослідах гербіциди проявляли певну фрітотоксичну дію. ІІї дія була різною і залежала як від хімічної природи самого препарату, так і від норми його витрати. Найбільш потужну фітотоксичність проявляв гербіцид Фронтьєр Оптіма,72 к. е. у нормі витрати 1,2 л/га (варіант 3). Навіть наявність фізичного адсорбенту не компенсувала потужної токсичної дії такого препарату до рослин культури. Фітотоксична дія гербіциду знижувала кількість сходів рослин культури у посівах на $35,1 \%$.

Використання у посівах рису гербіциду Дуал Голд, 960 EC 3 фрізичним адсорбентом (варіант 4) теж проявляла ефрект фітотоксичності. Проте він був істотно мен- шим порівняно з показниками попереднього варіанта досліду. Зниження густоти рослин культури від застосування гербіциду Дуал Голд, 960ЕС з адсорбентом становило в середньому 16,9\%. Обліки чисельності сходів бур'янів на час формування трьох листків у рослин культури у посівах забур'яненого контролю (варіант 1) фріксували дуже високий рівень забур'яненості. В середньому за роки проведення досліджень кількість сходів бур'янів у посівах рису становила 426,5 шт./м². 3 них сходи проса півнячого складали 281,3 шт./м², або 65,9\%, у структурі забур'яненості. Використання для контролювання проростків і сходів бур'янів можливості гербіциду Комманд,48КЕ у нормі витрати 0,5 л/га (варіант 2) істотно змінювало ситуацію забур'яненості посівів. Загальний показник зниження кількості сходів бур'янів складав 46,1\%. Такі види, як щириця звичайна (загнута), знижували свою присутність у посівах рису на 80,6\%, куга гострокінцева - на $73,3 \%$, лобода біла - на 67,8\%. Проте найбільш масовий вид бур'янів, а саме просо півняче, знижував свою присутність лише на 27,7\%. Біохімічне спрямування дії гербіциду Комманд 48КЕ - це види дводольних бур'янів, які у структурі забур'яненості посівів рису були в мінімумі (табл. 2).

Використання у посівах рису гербіциду Фронтьєр Оптіма, (д. р. диметиламід-П, 720 г/л) к. е. у нормі витрати 1,4 л/газ (варіант 4) вимагало захисту рослин культури від негативного впливу такого препарату, тому гербіцид Фронтьєр Оптіма, 72 к. е. застосовували 3 фрізичним адсорбентом безпосередньо до рослин культури. Загальний рівень зниження чисельності сходів бур'янів у посівах рису становив 77,1\%. 3 них рослини найбільш масового виду бур'янів, а саме проса півнячого, знижували свою чисельність на $77,2 \%$.

Для порівняння, кількість сходів бур'яну цього виду у посівах рису після застосування гербіцидів ґрунтової дії

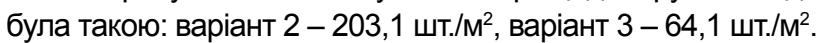
Такий гербіцид проявляв досить низьку активність до проростків і сходів рослин лободи білої, а саме зниження на $41,7 \%$, куги гострокінцевої (зниження на $68,9 \%$ ).

Проте загальне зниження чисельності сходів бур'янів у посівах рису було на рівні, що перевищував показники у посівах варіанта 2, на $31 \%$.

Таблиця 1 - Рівень фітотоксичності гербіцидів ґрунтової дії з адсорбентами (\% зниження густоти посівів) до рослин рису, 2018-2020 рр.

\begin{tabular}{|c|c|c|c|c|c|}
\hline \multirow{2}{*}{$\begin{array}{l}\text { Варіанти } \\
\text { досліду }\end{array}$} & \multirow{2}{*}{$\begin{array}{c}\text { Гербіциди і норми їх } \\
\text { витрати, л/га }\end{array}$} & \multirow{2}{*}{$\begin{array}{c}\text { Норма висіву } \\
\text { зернівок, } \\
\text { шт./м² }\end{array}$} & \multicolumn{2}{|c|}{$\begin{array}{c}\text { Польова схожість } \\
\text { зернівок рису }\end{array}$} & \multirow{2}{*}{$\begin{array}{c}\text { Зниження густоти сходів } \\
\text { через фітотоксичність } \\
\text { гербіцидів, \% }\end{array}$} \\
\hline & & & шт./M & $\begin{array}{c}\text { зниження до } \\
\text { лабораторної, \% }\end{array}$ & \\
\hline 1 & $\begin{array}{l}\text { Контроль без застосу- } \\
\text { вання гербіцидів } \\
\end{array}$ & 667 & 344 & 51,2 & 0 \\
\hline 2 & $\begin{array}{l}\text { Комманд, } 48 \text { КЕ у нормі } \\
0,5 \text { л/га }\end{array}$ & 667 & 167 & 51,2 & 23,8 \\
\hline 3 & $\begin{array}{l}\text { Фронтьєр Оптіма, } \\
\text { к. с. у нормі 1,2 л/га.+ } \\
\text { адсорбент } \\
\end{array}$ & 667 & 92 & 51,2 & 35,1 \\
\hline 4 & $\begin{array}{l}\text { Дуал Голд, } \\
960 \text { К.С у нормі 1,4 л/га.+ } \\
\text { адсорбент }\end{array}$ & 667 & 213 & 51,2 & 16,9 \\
\hline 5 & $\begin{array}{l}\text { Контроль } \\
\text { без бур'янів }\end{array}$ & 667 & 338 & 51,2 & 0 \\
\hline
\end{tabular}


Таблиця 2 - Ефективність контролювання сходів бур'янів гербіцидами ґрунтової дії з адсорбентом у посівах рису, 2018-2020 рр.

\begin{tabular}{|c|c|c|c|c|c|c|c|}
\hline \multirow{3}{*}{ Види бур'янів } & \multicolumn{7}{|c|}{ Варіанти досліду } \\
\hline & \multirow{2}{*}{$\frac{1}{\omega \tau . / M^{2}}$} & \multicolumn{2}{|r|}{2} & \multicolumn{2}{|r|}{3} & \multicolumn{2}{|r|}{4} \\
\hline & & шт./M² & $\begin{array}{c}\text { зниження } \\
\text { чисельності, \% }\end{array}$ & шт./M² & $\begin{array}{c}\text { зниження } \\
\text { чисельності, \% }\end{array}$ & шт./M² & $\begin{array}{c}\text { зниження } \\
\text { чисельності, \% }\end{array}$ \\
\hline Просо півняче & 281,3 & 203,1 & 27,7 & 64,1 & 77,2 & 51,2 & 81,8 \\
\hline Лобода біла & 11,5 & 3,5 & 67,8 & 6,7 & 41,7 & 7,4 & 35,7 \\
\hline Куга гострокінцева & 43,1 & 11,9 & 73,3 & 13,4 & 68,9 & 11,9 & 72,9 \\
\hline Подорожник великий & 4,5 & 1,5 & 66,7 & 1,4 & 68,8 & 3,9 & 13,3 \\
\hline Березка польова & 1,7 & 1,8 & 0 & 2,9 & 0 & 2,1 & 0 \\
\hline Портулак городній & 54,3 & 0,9 & 98,3 & 2,3 & 95,8 & 1,9 & 96,5 \\
\hline Щириця звичайна & 10,8 & 2,1 & 80,6 & 2,1 & 80,5 & 1,2 & 88,7 \\
\hline Паслін чорний & 6,1 & 1,7 & 72,1 & 1,5 & 75,4 & 1,7 & 72,1 \\
\hline Інші види & 13,2 & 3,5 & 73,5 & 3,5 & 73,5 & 2,7 & 79,5 \\
\hline Бур'яни всього & 426,5 & 230,0 & 46,1 & 97,9 & 77,1 & 84,0 & 80,3 \\
\hline $\mathrm{HIP}_{0,05}$ & 26,6 & & & & & & \\
\hline
\end{tabular}

У посівах рису варіанта 4 для контролювання проростків і сходів бур'янів було використано гербіцид Дуал Голд, 960 EC у нормі витрати 1,4 л/га із застосуванням фрізичного адсорбенту для захисту рослин культури від фітотоксичної дії препарату. Дуал Голд, 960 EC має біохімічне спрямування насамперед проти рослин ботанічної родини Тонконогові (Злакові).

Загальне зниження чисельності сходів бур'янів складало 80,3\%, з них кількість сходів рослин проса півнячого зменшувалась на $81,8 \%$, лободи білої - на 35,7\%, куги гострокінцевої - на 72,9\%, щириці звичайної (загнутої) - на $88,7 \%$.

Активність захисної дії гербіцидів, що діють через ґрунт, не завершувала заходи захисту посівів рису, а лише готувала вихідні позиції для застосування гербіциду по сходах. У дослідах таким гербіцидом був препарат Топшот, 113 ОД у нормі витрати 3,0 л/га. Посіви рису обприскували у фазі фрормування трьох листків у рослин культури. На час проведення обприскувань посівів рису по сходах гербіцидом рівень присутності сходів у бур'янів за варіантами істотно різнився. У посівах варіанта 2 після застосування Гербіциду Комманд, 48 KЕ сходів бур'янів було 230,0 шт./M², на ділянках варіанта 3 (після внесення гербіциду Фронтьєр Оптіма, 72 к. е. 3 адсорбентом) бур'янів було 97,9 шт./M², на ділянках варіанта 4 (після застосування гербіциду Дуал Голд, 960ЕС з адсорбентом) були присутні 84,0 шт./м² сходів бур'янів. Відповідно, навіть за однакового рівня захисної дії гербіциду Топшот, 113 ОД на сходи бур'янів у посівах рису наступний рівень їх забур'яненості може бути різним, як і їх здатність формувати свою масу та негативно впливати на рослини культури.

Дія гербіциду у посівах рису забезпечувала загальне зниження чисельності бур'янів, що мало такі показники: у посівах варіанта 2 (захисна дія гербіциду Комманд, 48 KE і наступна дія Топшот, 113 ОД) воно становило $71,7 \%$, у посівах варіанта 3 (захисна дія гербіциду Фронтьєр Оптима,72 к. е. з адсорбентом і наступна дія Топшот, 113 ОД) - 88,4\%. У посівах варіанта 4 захисна дія гербіциду Дуал Голд, 960 EC з адсорбентом і наступна дія Топшот, 113 ОД забезпечували зниження кількості сходів бур'янів на $95,1 \%$.

Рослини бур'янів, що виживали після застосування систем захисту посівів рису, протягом наступної вегетації формували свою масу. Обліки, які проводили через 100 діб після появи сходів рослин культури, фріксували найбільший обсяг формування сирої маси бур'янів у посівах варіанта 1 (забур'янений контроль).

Він становив 2473 г/м². Умови гострої конкуренції з бур'янами за фактори життя обмежували можливості рослин рису у формуванні урожаю. Рівень урожайності таких посівів становив у середньому 2,71 т/га, або 19,5\% від максимального в дослідах (варіант 5) (табл. 3).

Застосування системи гербіцидів у посівах варіанта 2 істотно змінювало ситуацію і обмежувало потенціал бур'янів сформувати свою масу. На час проведення обліків вона становила 821 г/м², або 32,8\% від максимального обсягу (варіант 1). Рівень урожайності посівів

Таблиця 3 - Ефективність контролювання бур'янів, (зниження чисельності, \%, та маси, г/м²) і урожайність (т/га) посівів рису посівного, 2018-2020рр.

\begin{tabular}{|c|c|c|c|c|c|c|c|}
\hline \multirow{3}{*}{$\begin{array}{c}\text { Варіанти } \\
\text { досліду }\end{array}$} & \multirow{3}{*}{$\begin{array}{c}\text { Зниження } \\
\text { чисельності } \\
\text { бур'янів } \\
\text { гербіцидами, \% }\end{array}$} & \multicolumn{3}{|c|}{ Маса бур'янів, г/м² } & \multirow{3}{*}{$\begin{array}{c}\text { Густота } \\
\text { стояння, } \\
\text { шт./M² }\end{array}$} & \multirow{3}{*}{$\begin{array}{c}\text { Урожайність, } \\
\text { т/га }\end{array}$} & \multirow{3}{*}{$\begin{array}{c}\text { Вологість } \\
\text { зернівок, \% }\end{array}$} \\
\hline & & \multirow[b]{2}{*}{ всього } & \multicolumn{2}{|c|}{ зокрема: } & & & \\
\hline & & & дводольні & однодольні & & & \\
\hline 1 & 0 & 2473 & 628 & 1845 & 341 & 2,71 & 17,12 \\
\hline 2 & 71,7 & 821 & 216 & 605 & 162 & 10,24 & 17,09 \\
\hline 3 & 88,4 & 412 & 114 & 298 & 92 & 12,10 & 17,11 \\
\hline 4 & 95,1 & 244 & 57 & 187 & 211 & 12,81 & 17,07 \\
\hline 5 & 100 & 0 & 0 & 0 & 334 & 13,92 & 17,06 \\
\hline $\mathrm{HIP}_{0,05}$ & & 38,9 & & & & 0,26 & 0,19 \\
\hline
\end{tabular}


рису досягав 10,24 т/га. Такий рівень урожайності становив 73,6\% від максимального.

У посівах рису на ділянках варіанта 3 сумарна дія гербіцидів на рослини бур'янів була більш ефективною, тому обсяги маси бур'янів перебували на рівні 412 г/м², або 16,7\% від обсягів у посівах забур'яненого контролю (варіант 1). Рослини культури мали можливість більш повно використовувати фрактори середовища і формувати урожай зернівок. Урожайність посівів рису за таких умов вегетації складала в середньому 12,10 т/га, або 86,9\% від рівня урожайності, який формували посіви, що вегетували без негативного впливу бур'янів (варіант 5).

Використання для захисту посівів рису від бур'янів послідовного поєднання потенціалу дії гербіцидів Дуал Голд, 960 КЕ з адсорбентом і Топшот, 113 ОД (варіант 4) обмежувало можливості бур'янів нарощувати свою кількість та фрормувати свою масу на рівні 244 г/м², або 9,9\% від максимальних показників у дослідах (варіант 1). Відповідно, показники урожайності зернівок таких посівів рису становили в середньому 12,81 т/га, або 92,0\% від найбільшого рівня урожайності в дослідах (варіант 5). Вологість урожаю зернівок становила $17,07 \%$, тобто результати вегетації таких посівів та їх урожайність були найбільш близькими до посівів, що вегетували до збирання урожаю без негативного впливу бур'янів (варіант 5).

Посіви рису, у процесі вегетації яких для захисту від негативного впливу бур'янів застосовували п'ять послідовних ручних прополювань, рівень урожайності був найвищим, а саме 13,92 т/га, з вологістю зернівок $17,06 \%$.

Висновки. Рівень потенційної засміченості верхнього (0-10 см) горизонту орного шару живим насінням бур'янів у рисових чеках $є$ значним і досягає в середньому 12 987,8 шт./м². 3 них найбільш масовим було насіння проса півнячого, а саме 1381 шт./м².

1) На час проведення обліків (формування у рослин рису трьох листків) кількість сходів бур'янів у посівах була дуже високою і становила в середньому 426,5 шт./M² посівів. 3 них сходи проса півнячого (Echinochloa crus-galli (L.) Pal. Beauv.) складали 281,3 шт./м², або 65,9\% від загальної кількості рослин бур'янів, портулаку городнього (Portulaca oleraceae L.) - 54,3 шт./M², або 12,7\%, куги гострокінцевої (Scirpus mucronotus L.) - 43,1 шт./м², або 10,1\%.

2) Для ефективного контролювання високого рівня забур'яненості посівів рису було застосовано системи послідовного внесення гербіцидів у ґрунт і по сходах. Використання гербіцидів ґрунтової дії 3 біохімічним спрямуванням контролювання рослин з ботанічної родини Тонконогові вимагало застосування фрізичних адсорбентів для захисту рослин культури.

3) Гербіциди ґрунтової дії навіть з адсорбентами частково проявляли фрітотоксичну дію до проростків і сходів рослин рису. Найвищий рівень фітотоксичності було зафріксовано у гербіциду Фронтьєр Оптіма, 72 к. е., адже зниження густоти посівів рису становило $35,1 \%$, найнижчий рівень зафіксовано у гербіциду Дуал Голд, 960 EC, адже зниження складало 16,9\%. Ефективність дії ґрунтових гербіцидів на проростки і сходи бур'янів була такою: Комманд, $48 \mathrm{KE}$ до 46,1\%, Фронтьєр Оптіми (з адсорбентом) до $77,1 \%$, Дуал Голд, 960 ЕС з адсорбентом до 80,3\%.
4) Використання по сходах гербіциду Топшот, 113 ОД м. д. посилювало і продовжувало захисний есрект гербіцидів ґрунтової дії, а також обмежувало здатність рослин бур'янів фоомувати свою масу у посівах рису на 66,8-90,1\%. Системи захисту від бур'янів забезпечили отримання урожайності посівів рису на таких рівнях: варіант 2 - 10,24 т/га, або 73,6\%, варіант 3 - 12,1 т/га, або 86,9\%, варіант 4 - 12,81 т/га, або 92,0\% від максимального у дослідах 13,92 т/га (варіант 5).

5) Результати досліджень підтверджують наявність вагомих резервів удосконалення систем захисту посівів рису від бур'янів шляхом адаптації відомих гербіцидів для контролювання найбільш масових і проблемних бур'янів у рисових чеках. Збільшення кількості препаратів з різною дією у системах захисту посівів рису знижує небезпеку формування резистентних популяцій бур'янів і забезпечує їх високу ефективність.

\section{СПИСОК ВИКОРИСТАНОÏ ЛІТЕРАТУРИ}

1. Ванцовський А.А. Культура рису на Україні : монографія. Херсон : Айлант, 2004. 172 с.

2. Вожегов С.Г. Теоретичне та агроекологічне обґрунтування технологій вирощування сільськогосподарських культур в рисових сівозмінах : дис. ... докт. с.-Г. наук : спец. 06.01.02. Херсон, 2016. 387 с.

3. Andreasen C., Jensen H.A., Jensen S.M. Decreasing diversity in the soil seed bank after 50 years in Danish arable fields. Agriculture, Ecosystems and Environment. 2018. Vol. 259. P. 61-71.

4. Amaugo G.O., Emosairue S.O. Effect of neem seed kernel extracts on stem borer damage and yield of upland rice in southeastern Nigeria. Intern. Rice Research Notes. 2005. № 30.1. P. 24

5. Мордерер Е.Ю. Коррекция избирательной фритотоксичности гербицидов в тройных комплексах. Физиология и биохимия культурных растений. 2000. T. 30. № 3. С. 181-186.

6. Tautges N.E., Burke I.C., Borrelli K., Fuerst E.P. Competitive ability of rotational crops with dryland organic wheat production systems. Reneweble Agriculture and Food Systems. 2017. Vol. 32. P. 57-68.

7. Воронюк 3.С., Дудченко В.В., Дудченко Т.В. Захист рису від шкідників, хвороб та бур'янів. Пропозиція. 2006. № 8. C. 74-80.

8. Lyon D.J., Burk I.C., Hultting A.G., Campbell J.M. Integrated Management if Mayweed Chamomile in Wheat and Pulse Crop Production Systems. Pullman, WA : Washington State University Publications PNW695, 2017. 106 p.

9. Авакян К.М., Агарков В.Д., Алексеенко Е.В., Касьянов А.И. и др. Система рисоводства Краснодарского края. Краснодар, 2006. С. 253-261.

10. Heap I. M. The International Survey of Herbicide Resistant Weeds. URL: http://www.weedscience.org (дата звернення: 20.12.2018).

11. Озерова Л.В., Швартау В.В. Механізми дії сучасних гербіцидів - інгібіторів ацетил-КоА-карбоксилази. Фізіологія та біохімія культурних рослин. 2005. T. 37. № 6. C. 486-494.

12. Barret S.C., Harder L.D. The ecology of mating and its evolutionary consequences in seed plants. Annual Review of Ecology, Evolution and Systematics. 2017. Vol. 48. P. 135-157. 
13. Bust R., Goggin D.E., Heap I.M. et al. Weed resistance to synthetic auxin herbicides. Pest Management Science. 2018. Vol. 74. P. 2265-2276.

14. Ricciardi A., Blackburn T.M., Carlton J.T. et al. Invasion science: a horizon scans of emerging challenges and opportunities. Trends in Ecology \& Evolution. 2017. Vol. 32. P. 464-474.

15. Дудченко В.В., Вожегов С.Г., Морозов Р.В. та ін. Диверсифікація виробництва рису як перспективний напрям формування конкурентоспроможності продукції галузі рисівництва в Україні. Таврійський науковий вісник. 2014. Вип. 87. С. 33-39.

16. Прадун В.П. Підвищення ефективності використання потенціалу зрошуваного землеробства в АР Крим. Вісник аграрної науки. 2001. № 7. С. 64-66.

17. Іващенко О.О., Іващенко О.О. Загальна гербологія : монографрія. Київ : Фенікс, 2019. 702 с. URL: https://doi.agr/10.36495/ISBN-978-966-136-649-6/2019 (дата звернення: 12.09.2020).

18. O'Leary G., Aggarwal P., Calderini D., Crauford P., Eigenbrode $S$. et al. Challenges and responses to ongoing and projected climate change for dryland cereal production systems throughout the world. Agronomy. 2018. Vol. 8. P. 34

19. Soni N., Nissen S.J., Westra P., Norsworthy J.K., Walson M.J., Gaines T.A. Seed retention of winter annual grass weeds at winter wheat harvest maturity shows potential for harvest weed seed control. Weed Technology. 2019. Vol. 34 (2). P. 266-271.

20. Швартау В.В. Гербіциди. Т. 2 : Основи регуляції фрітотоксичності та фрізико-хімічні і біологічні властивості. Київ : Логос, 2009. 1046 с.

21. Jungueira L.V., Mendes K.F., Soursa R.N., Almeida C.S., Alonso F.G., Tornisielo V.L. Sorption-desorption isotherms and biodegradation of glyphosate in two tropical soils aged with eucalyptus biochar. Archives of agronomy and Soil Science. 2019. P. 1-18.

22. Методики випробування і застосування пестицидів / за ред. С.О. Трибеля. Київ : Світ, 2001. 448 с.

23. Ковальчук В.П., Васильев В.Г., Бойко А.В., Зосимов В.Д. Сборник методов исследования почв и растений. Киев : Институт сахарной свеклы НААН, 2010. 252 c.

24. Роїк М.В., Гізбуллін Н.Г., Сінченко В.М., Присяжнюк O.І. та ін. Методики проведення досліджень у буряківництві. Київ : ФОП Корзун Д.Ю., 2014. 374 с.

\section{REFERENCES:}

1. Vantsovskiy, A.A. (2004). Kultura risu na Ukrayini [Rice culture in Ukraine]. Herson: Aylant [in Ukrainian].

2. Vozhegov, S.G. (2016). Teoretichne ta agroekologichne obgruntuvannya tehnologiy viroschuvannya silskogospodarskih kultur $v$ risovih sivozminah [Theoretical and agroecological substantiation of technologies of cultivation of agricultural crops in rice crop rotations]. Extended abstract of Doctor's thesis. Herson [in Ukrainian].

3. Andreasen, C., Jensen, H.A. \& Jensen, S.M. (2018). Decreasing diversity in the soil seed bank after 50 years in Danish arable fields. Agriculture, Ecosystems and Environment, 259, 61-71 [in English].

4. Amaugo, G.O. \& Emosairue, S.O. (2005). Effect of neem seed kernel extracts on stem borer damage and yield of upland rice in southeastern Nigeria. Intern. Rice Research Notes, 30 (1), 24 [in English].

5. Morderer, E.Yu. (2000). Korrektsiya izbiratelnoy fitotoksichnosti gerbitsidov $v$ troynyih kompleksah. Fiziologiya $i$ biohimiya kulturnyih rasteniy - Physiology and biochemistry of cultivated plants, 30 (3), 181-186 [in English].

6. Tautges, N.E., Burke, I.C., Borrelli, K. \& Fuerst, E.P. (2017). Competitive ability of rotational crops with dryland organic wheat production systems. Reneweble Agriculture and Food Systems, 32, 57-68 [in English].

7. Voronyuk, Z.S., Dudchenko, V.V. \& Dudchenko, T.V. (2006). Zahist risu vid shkldniklv, hvorob ta bur'yaniv [Protect rice from pests, diseases and weeds Protect rice from pests, diseases and weeds]. Propoziciya Offer, 8, 74-80 [in Ukrainian].

8. Lyon, D.J., Burk, I.C., Hultting, A.G. \& Campbell, J.M. (2017). Integrated Management if Mayweed Chamomile in Wheat and Pulse Crop Production Systems. Pullman, WA: Washington State University Publications PNW695 [in English].

9. Avakyan, K.M. et al. (2006). Sistema risovodstva Krasnodarskogo kraya [Rice-growing system of the Krasnodar Territory]. Krasnodar [in Russian].

10. Heap, I.M. (2018). The International Survey of Herbicide Resistant Weeds. URL: http://www.weedscience.org [in English].

11. Ozerova, L.V. \& Shvartau, V.V. (2005). Mehanizmi diyi suchasnih gerbitsidiv - Ingibitoriv atsetil-KoA-karboksilazi [Mechanisms of action of modern herbicides - acetyl-CoA-carboxylase inhibitors]. Fiziologiya ta biohimiya kulturnih roslin - Physiology and biochemistry of cultivated plants, 37 (6), 486-494 [in Ukrainian].

12. Barret, S.C. \& Harder, L.D. (2017). The ecology of mating and its evolutionary consequences in seed plants. Annual Review of Ecology, Evolution and Systematics, 48, 135-157 [in English].

13. Bust, R., Goggin, D.E. \& Heap, I.M. et al. (2018). Weed resistance to synthetic auxin herbicides. Pest Management Science, 74, 2265-2276 [in English].

14. Ricciardi, A., Blackburn, T.M. \& Carlton, J.T. et al. (2017). Invasion science: a horizon scans of emerging challenges and opportunities. Trends in Ecology \& Evolution, 32, 464-474 [in English].

15. Dudchenko, V.V. et al. (2014). Diversifikatsiya virobnitstva risu yak perspektivniy napryam formuvannya konkurentospromozhnosti produktsiyi galuzi risivnitstva $v$ Ukrayini. [Diversification of rice production as a promising direction for the formation of competitiveness of rice products in Ukraine Diversification of rice production as a promising direction for the formation of competitiveness of rice products in Ukraine]. Tavrijskij naukovij visnik Taurian Scientific Bulletin, 87, 33-39 [in Ukrainian].

16. Pradun, V.P. (2001). Pidvischennya efektivnosti vikoristannya potentsialu zroshuvanogo zemlerobstva $\vee A R$ Krim [Improving the efficiency of using the potential of irrigated agriculture in the Autonomous Republic of Crimea]. Visnik agrarnoyi nauki - Bulletin of Agricultural Science, 7, 64-66. URL: https://doi.agr/10.36495/ISBN 978-966-136-649-6/2019 [in Ukrainian].

17. Ivaschenko, O.O. \& Ivaschenko, O.O. (2019). Zagalna gerbologiya [General Herbology]. Kyiv. URL: https:// doi.agr/10.36495/ISBN-978-966-136-649-6/2019 [in Ukrainian].

18. O'Leary, G., Aggarwal, P., Calderini, D., Crauford, P. \& Eigenbrode, S. et al. (2018). Challenges and responses to ongoing and projected climate change for dryland cereal production systems throughout the world. Agronomy, 8, 34 [in English].

19. Soni, N., Nissen, S.J., Westra, P., Norsworthy, J.K., Walson, M.J. \& Gaines, T.A. et al. (2019). Seed retention 
of winter annual grass weeds at winter wheat harvest maturity shows potential for harvest weed seed control. Weed Technology, 34 (2), 266-271 [in English].

20. Shvartau, V.V. (2009). Gerbitsidi. Osnovi regulyatsiyi fitotoksichnosti ta fiziko-himichni i biologichni vlastivosti [Fundamentals of phytotoxicity regulation and physicochemical and biological properties]. (Vol. 2). Kyiv: Logos [in Ukrainian].

21. Jungueira, L.V., Mendes, K.F., Soursa, R.N., Almeida, C.S., Alonso, F.G. \& Tornisielo, V.L. (2019). Sorption-desorption isotherms and biodegradation of glyphosate in two tropical soils aged with eucalyptus biochar. Archives of agronomy and Soil Science, 1-18 [in English].

22. Tribelya, S.O. (ed.) (2001). Metodiki viprobuvannya $i$ zastosuvannya pestitsidiv [Methods of testing and application of pesticides]. Kyiv: Svit [in Ukrainian].

23. Kovalchuk, V.P., Vasilev, V.G., Boyko, A.V. \& Zosimov, V.D. (2010). Sbornik metodov issledovaniya pochv $i$ rasteniy [Collection of methods for the study of soils and plants]. Kyiv: Institut saharnoy sveklyi NAAN [in Ukrainian].

24. Royik, M.V. et al. Gizbullina, N.G. (ed.) (2014). Metodiki provedennya doslidzhen u buryakivnitstvi [Research methods in beet growing]. Kyiv: FOP Korzun D.Y. [in Ukrainian].

Цілинко Л.М. Раціональний шлях підвищення рівня ефективності системи захисту посівів рису від бур'янів

Метою дослідження $€$ оцінювання причин недостатньої ефективності застосування відомих гербіцидів і розроблення шляхів надійного контролювання бур'янів та отримання високих врожаїв рису посівного. Методи. Досліди були польовими дрібно ділянковими, їх проводили у 2018-2020 рр. у посівах (рисових чеках) Інституту рису НААН України. Обліки та аналізи проводили відповідно до специфіки вимог «Методики випробування й застосування пестицидів» за редакцією професора С.О. Трибеля, «Методів досліджень ґрунтів і рослин» та «Методики проведення досліджень у буряківництві». Урожайність посівів рису визначали шляхом суцільного збирання облікових ділянок на всіх повтореннях варіантів спеціальним селекційним комбайном «Сампо$2000 »$. Результати. В результаті аналізів проб ґрунту 3 рисових чеків установлено, що найбільші запаси живого насіння присутні у горизонті 0-10 см, становлять

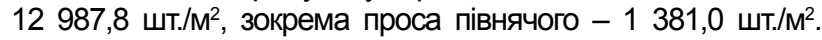
$\mathrm{Ha}$ ділянках варіанта 1 (забур'янений контроль) загальна кількість сходів бур'янів становила 426,5 шт./M². 3 них сходи проса півнячого (Echinochloa crus-galli (L.) Pal. Beauv.) складали 281,3 шт./M², або 65,9\% від загальної кількості рослин бур'янів. Гербіциди ґрунтової дії навіть із фрізичними адсорбентами частково проявляли фітотоксичну дію до проростків і сходів рослин рису. Гербіцид Фронтьєр Оптіма, 72 к. е. у нормі витрати 1,2 л/га (варіант 3) з адсорбентом знижував густоту посівів рису на $35,1 \%$, Дуал Голд, 960 ЕС у нормі витрати 1,4 л/га і наявністю адсорбенту - на 16,9\% (варіант 4). Захисна ефрективність дії ґрунтових гербіцидів була різною: Комманд, 48 КЕ у нормі витрати 0,5 л/га (варіант 2) знижував чисельність бур'янів на 46,1\%, Фронтьєр Оптіма (з адсорбентом) - на 77,1\%, Дуал Голд, 960 EC з адсорбентом - на 80,3\%. Використання по сходах гербіциду Топшот, 113 ОД м. д., у нормі витрати 3,0 л/га (варіанти 2, 3, 4) обмежувало здатність бур'янів формувати у посівах рису свою масу на 66,8-90,1\%. Системи захисту від бур'янів забезпечили отримання урожайно- сті посівів рису на таких рівнях: варіант $1-2,71$ т/га, або $19,5 \%$, варіант 2 - 10,24 т/га, або $73,6 \%$, варіант 3 12,1 т/га, або 86,9\%, варіант 4 - 12,81 т/га, або 92,0\% від максимального у дослідах 13,92 т/га (варіант 5).

Висновки. Результати досліджень підтверджують наявність вагомих резервів удосконалення систем захисту посівів рису від бур'янів шляхом підбору і застосування фізичних адсорбентів до відомих гербіцидів для контролювання найбільш масових і проблемних бур'янів у рисових чеках.

Ключові слова: адсорбент, види дводольних, гербіциди, врожайність, фрітотоксичність.

Tsylinko L.N. Rational way to increase the efficiency of rice crop protection systems from weeds

The purpose of the research was to assess the reasons for the insufficient effectiveness of the use of known herbicides and to develop ways to reliably control weeds and obtain high yields of sowing rice. Methods. The experiments were field trials. They were carried out in 2018-2020 in crops (rice paddies) of the Rice Institute of the National Academy of Sciences of Ukraine. The counts and analyzes were carried out in accordance with the requirements of the "Methods of testing and the use of pesticides)", edited by prof. S.A. Triebel, "Soil and Plant Research Methods" and "Research Methods in Beet Growing". The yield of rice crops was determined by continuous harvesting of registration plots on all repetitions of the variants with a special selection harvester "Sampo 2000". Results. As a result of analyzes of soil samples from rice paddies, it was found that the largest reserves of live seeds are present in the soil horizon of rice paddies $0-10 \mathrm{~cm}$ and amount to $12987.8 \mathrm{pcs} / \mathrm{m}^{2}$, including 1381 chicken $\mathrm{millet} / \mathrm{m}^{2}$.

On plots of option 1 (weed control), the total number of weed seedlings is $426.5 \mathrm{pcs} / \mathrm{m}^{2}$. Of these, sprouts of chicken millet (Echinochloa crus-galli (L.) Pal. Beauv.) $281.3 \mathrm{pcs} / \mathrm{m}^{2}$, or $65.9 \%$ of the total number of weed plants. Soil hebicides, even with the presence of a physical adsorbent, partially showed a phytotoxic effect on seedlings and seedlings of rice plants. Herbicide Frontier Opttma, $72 \mathrm{k}$. e. at a consumption rate of $1.2 \mathrm{l} / \mathrm{ha}$ and the presence of an adsorbent (option 3 ) reduced the density of rice crops by $35.1 \%$, Dual Gold, $960 \mathrm{ES}$ at a rate of $1.4 \mathrm{l} / \mathrm{ha}$ and the presence of an adsorbent by $16.9 \%$ (option 4 ). The protective effectiveness of the action of soil herbicides was different. Command, $48 \mathrm{KE}$ at a consumption rate of $0.5 \mathrm{l} / \mathrm{ha}$ (option 2) reduced the number of weeds by $46.1 \%$, Front Optima (with adsorbent) - by $77.1 \%$, Dual Gold, 960ES with adsorbent - by $80.3 \%$. Application of herbicide Topshot on germination, $113 \mathrm{OD}$ ppm at a consumption rate of $3.0 \mathrm{l} / \mathrm{ha}$ (variants $2,3,4$ ) limited the ability of weeds to form their weight in rice crops by $66.8-90.1 \%$. Weed control systems ensured the yield of rice crops at the level: option 1-2.71 t/ha, or $19.5 \%$, option $2-10.24 \mathrm{t} /$ ha or $73.6 \%$, option $312.1 \mathrm{t} / \mathrm{ha}$ or $86.9 \%$, option $4-12.81 \mathrm{t} / \mathrm{ha}$ or $92.0 \%$ of the maximum in experiments - 13.92 t/ha (option 5). Conclusions. The research results confirm the presence of significant reserves for improving the systems of protecting rice crops from weeds by selecting and applying physical adsorbents to known herbicides to control the most common and problematic types of weeds in rice paddies.

Key words: adsorbent, dicotyledonous species, herbicides, productivity, phytotoxicity. 